\title{
Cyberspace e os sujeitos da interatividade
}

\author{
Francisco Menezes Martins' \\ UTP
}

\begin{abstract}
Resumo: $O$ texto considera o discurso da comunicação uma das fábulas que acompanha o sujeito, após o crepúsculo da metafísica. Para tal, aborda as relações entre a cibercultura e o pensamento contemporêneo através das trilhas e rastros das possibilidades interativas na internet.
\end{abstract}

Palavras-Chave: Cibercultura - Comunicação - Internet

Abstract: The paper Considers the speech of the communication one of the fables that accompanies the subject, after the twilight of the metaphysics. For such, it approaches the relationships between the cyberculture and the actually thought through the trails and traces of the interactive possibilities in the internet

Word-key: Cyberculture - Communication - Internet.

\footnotetext{
${ }^{1}$ Professor do PPGCOM - UTP

Líder de Pesquisa do Grupo de Tecnologias do Imaginário - PUCRS/UTP

Membro do Conselho da Associação Brasileira dos Pesquisadores em Cibercultura - Abciber Doutor em Comunicação - UCM/Espanha
} 
Após séculos de metafísica como o além do perceptível, a época atual reserva uma ruptura fundamental no que seriam as grandes certezas do mundo. Cada verdade que ressoou por gerações entra em choque com sua própria verificação.

O sujeito sempre tentou adaptar o mundo ao seu olhar, subestimando a complexidade de tal segredo, como se a constatação do mundo passasse a ser verificada numa espécie de revisionismo das cenas do mundo, que, no fundo, nem se sabe se chegaram a constituir o mundo anterior à técnica, mas que agora permite a chegada dos trens do passado nas estações do presente.

Diante da impossibilidade de criar um mundo além deste, o que vale é criar um discurso para um mundo melhor que este, conforme o pensamento de Nietzsche (1996).

Deste modo, na incapacidade de interpretar o passado de uma maneira isenta ao sujeito, poderia-se tentar interpretar o presente como uma saturação do passado e um congestionamento de signos que desaceleram o sujeito, que poderia afirmar o desejo em seu devir, e aceleram o objeto em seu devir sedutor, por estar programado para tal.

No sentido das reflexões sobre os papéis dos sujeitos e objetos segundo a tradicional teoria da comunicação e sua transposição ao novo e pouco explorado tema da crise da epistemologia da comunicação com o advento do cyberspace, pesquisadores buscam uma posição de análise para a contextualização do receptor na internet.

Considerando uma das palavras-mestras de nosso tempo, para utilizar uma expressão de Edgar Morin(1984), a interatividade traz à tona uma nova forma de consumo dos conteúdos comunicacionais e, ao mesmo tempo, surge como uma nova forma de laços entre as pessoas, numa noção de tecno-socialidade.(Maffesoli,1996)

É pertinente a exposição da passagem de um receptor passivo a um receptor interativo, termo mais apropriado que receptor ativo, por ser visto, desde este ponto de vista, como a relação que se estabelece no contexto da superexposição às interatividades comunicacionais.

O receptor, por haver sido considerado um elemento passivo, segundo a escola funcionalista, não necessariamente deixou de ser passivo pela superação 
científica deste tipo de análise. Na verdade o receptor tem um instrumental baseado, na "tecnoburocracia da interatividade"(Trivinho in Martins e Silva, 1999), para relacionar-se com os produtores das informações que lhe interessam, mas no olho do furacão frankfurtiano se pode considerar que o receptor jamais tenha sido passivo.

Esta foi uma grande intenção de poder dos emissores e dos pensadores dos poderes da comunicação. Ou seja, um deslocamento no olhar da questão não implica que a descoberta do receptor-sujeito da pós-modernidade e da era digital tenha sido algo inédito.

Se há uma reestruturação das relações sociais, e que elas não têm por que serem melhores ou piores das anteriores à emergência das já nem tão novas assim tecnologias da comunicação. Também é pertinente tomar os receptores como produtores de sentido, como um agente comunicacional. É como levantar questões do tipo: a comunicação começa realmente no emissor? O meio é realmente a mensagem ou a mensagem é o meio de laços de socialidade?

Esta relação dialógica da comunicação é explorada por pensadores como Edgar Morin, que acredita que o diálogo da mundialização parte de sua visão da metáfora do holograma (1995)

Levando em conta esta idéia de Morin, nota-se que o receptor na internet é um sujeito mundializado. Sua relação interativa lhe permite o acesso potencial ao todo, à rede em si, e a cada uma de suas partes, os conteúdos, na forma do holograma, de maneira que cada site leva consigo as informações da rede, que segundo Pierre Lévy (1993) é o próprio espaço, ou o universo, como se refere Morin à Terra-pátria.

Parece ser consenso que vivemos a era do excesso de comunicação, ao contrário de outras épocas de restrições de ordem política e tecnológica. Assim, seguir argumentos que já tenham superado a clássica estrutura consagrada por Mcluhan (emissor-mensagem-receptor). Tal linearidade é um vestígio do raciocínio da modernidade, onde a capacidade intelectual do receptor é diminuída ao máximo, em nome do poder da transmissão. 
Seria ser oportuno retomar uma frase de José Ortega y Gasset: "Devemos agradecer que os positivistas tenham existido, porque, do contrário, nós teríamos que sê-los".

Esta irônica colocação de Ortega pode ser transcrita aos funcionalistas que dedicaram suas vidas aos estudos da comunicação, ainda que na ótica de Lucien Sfez (1994), eles tenham sido grandes contribuintes ao tautismo das pesquisas na área da comunicação.

Além da produção de sentido, concordo que a internet seja uma nova atmosfera das relações humanas, porém questiono se a sociabilidade seja o termo mais adequado, por envolver laços mecânicos. Ainda que seja virtual, a relação estabelecida é de socialidade, orgânica-virtual, ela envolve a liberdade de acesso, que neste sentido se configura no protocolo de acesso à web.

Os mapeamentos, neste sentido, são extremamente válidos, no momento em que buscamos consolidar os estudos sobre a comunicação no Cyberspace. Como integrante ativo em pesquisas nesta área, creio estarmos no caminho acertado. Devemos superar esta fase antes de nos aprofundarmos nas reflexões ou críticas à era da comunicação digital.

Parece que a comunicação estava sustentada por um modelo teórico já evaporado. Desta fragilidade teórica surgem as crises de orientação no campo das pesquisas. Foi somente a comunicação de massa transformar-se em redes comunicacionais informáticas para o modelo consolidado fracassar. Esta história já se repetiu em outras ciências como a física, a medicina ou a química. Mais próximas a nós, a psicanálise e a sociologia.

Chegou a vez da teoria da comunicação tornar-se uma ruína, como diz Eugênio Trivinho(1999). Se a comunicação no advento do cyberspace escapa às linhas de pesquisa, recorramos às redes de pesquisa, e, mais ainda, às redes de idéias. A virulência descrita por Jean Baudrillard deve ocorrer também no sentido de ampliarmos as órbitas da circulação do saber na efervescência de nossas discussões.

As colocações feitas sobre a internet parecem ser infinitas. Por isso, parece ser oportuno abrir novas perspectivas de abrangência deste fenômeno 
comunicacional da aurora do século XXI, buscando na interdisciplinaridade a contribuição de cada parte para a compreensão do holograma.

É verdade que nem tudo está no Cyberspace, mas é certo que através das superfícies da era do virtual (cyberspace, redes e telas), a cultura dita pós-moderna reverbera em ambos os lados da tela. Partindo da idéia de que a comunicação é a busca do duplo, vemos na visão de Baudrillard os sintomas descritos em $O$ Crime Perfeito (Baudrillard, 1996) de que o mundo engoliu seu duplo, no êxtase da comunicação da era do simulacro.Além disso, para Baudrillard o mundo é uma tela total:

"Vídeo, tela interativa, multimídia, internet, realidade virtual: a interatividade nos ameaça por toda parte. Por tudo mistura-se o que era separado; por tudo a distância é abolida: entre sexos, entre os pólos opostos, entre o palco e a platéia, entre os protagonistas da ação, entre o sujeito e o objeto, entre 0 real e seu duplo.”(Baudrillard,1997, p.145)

A reflexão de Baudrillard remete às idéias em sintonia com o contexto do receptor na internet, leva a estudos que analisam as fusões comunicacionais, que à guisa de polêmica amigável, são marca registrada do simulacro, fruto da acidez irônica do pensador Baudrillard, que não entende o apocalipse, nem tampouco a "lenda tecno-rosada" da era digital, mas compreende que até poucos anos

"las oposiciones sujeto/objeto y público y privado todavía tenían sentido. Esta era la época del descubrimiento y exploración de la vida diária, y la otra escena emergía a la sombra de la escena histórica.(..) Pero hoy ya no existen la escena y el espejo. Hay en cambio, una pantalla y una red. En lugar de la transcendencia reflexiva del espejo y la escena, hay una superfície no reflexiva, una superfície inmanente donde se despliegan las operaciones, la suave superfície operativo de la comunicación."(Baudrillard in Foster, 1988, p.188)

Já não se pode considerar valores dogmáticos e cristalizados como referências de uma verdade elevada a partir da antiga questão platônica do mundo verdadeiro, que Nietzsche procurou golpear com seu martelo nihilista na obra O Crepúsculo dos Ídolos, e que orientou o pensamento para uma superação da metafísica, a partir de Heidegger e com extensões a Gilles Deleuze, Jean-François Lyotard, Michel Foucault, Jacques Derrida, Michel Maffesoli, Jean Baudrillard e Gianni Vattimo, entre outros. 
Afinal, mencionar emissores e receptores na internet é um deslocamento para uma ontologia que já não obedece às relações do ser com os entes, mas a um universo técnico, uma atualização de seculares questões filosóficas que parecem ser um desafio às capacidades humanas de sentir e comunicar o mundo de seu tempo.

\section{Referências}

BAUDRILLARD, J. As estratégias fatais. Rio de Janeiro. Rocco. 1996.

BAUDRILLARD, J. El Crímen Perfecto. Barcelona. Anagrama. 1995.

BAUDRILLARD, J. A Transparência do Mal. Campinas. Papirus. 1992.

BAUDRILLARD, J. La Ilusión del Fin - la huelga de los acontecimientos. Barcelona. Anagrama. 1993

BAUDRILLARD, J. Simulacros e Simulação. Lisboa. Relógio D'água. 1991.

BAUDRILLARD, J. Tela Total, Porto Alegre. Editora Sulina. 1997.

FOSTER,H, HABERMAS, J, BAUDRILLARD,J. La Posmodernidad. Barcelona. Kairós. 1983.

LÉVY, P. Cibercultura. São Paulo, Editora 34. 1997.

LÉVY, P. O que é o virtual? Rio de Janeiro. Editora 34. 1996.

MAFFESOLI, M. A contemplação do mundo. Porto Alegre. Artes \& Ofícios. 1995.

MAFFESOLI, M. No Fundo das Aparências. Petrópolis. Ed. Vozes. 1996.

MARTINS,F.M, SILVA,J.M. Para Navegar no Século XXI. Porto Alegre. Editora Sulina/Edipucrs. 1999.

MORIN, E. Cultura de massas no século XX- O espírito do tempo. Rio de Janeiro. Forense. 1984

MORIN, E. O Método 5 - a humanidade da humanidade: a identidade humana. Porto Alegre. Editora Sulina. 2002.

MORIN, E. Terra-Pátria. Porto alegre. Editora Sulina. 1995.

NIETZSCHE, F. Genealogia da Moral. Lisboa. Editora Moraes. 1977. 
NIETZSCHE, F. Além do Bem e do Mal. São Paulo. Companhia das Letras. 1996.

NIETZSCHE, F. El ocaso de los ídolos. Madrid. M.E. Editores. 1993.

NIETZSCHE, F. Humano, demasiado humano. São Paulo. Companhia das Letras. 2000.

NIETZSCHE, F. El Caminante y su Sombra. Madrid. M.E. Editores. 1994.

ORTEGA y GASSET, J. La rebelión de las masas. Madrid. Alianza Editorial. 1993.

ORTEGA y GASSET, J. Meditación de la tecnica. Madrid. Alianza Editorial. 1992.

ORTEGA Y GASSET, J. Que es filosofia?. Madrid. Espasa Calpe. 1993.

SFEZ, L. Crítica da Comunicação. São Paulo. Loyola.1994.

SPENGLER, O. O homem e a técnica. Porto Alegre. Editora Globo. 1958

VATTIMO, G. Las aventuras de la diferencia - pensar después de Nietzsche y Heidegger, Barcelona. Península. 1996.

VIRILIO, P. Espaço Crítico. São Paulo. Editora 34. 1996. 